\title{
Digital Literacy of Lecturers as Whatsapp Group Users In Spreading Hoax Informations and Hate Speech
}

\author{
Intan Putri Cahyani \\ UPN Veteran Jakarta \\ E-mail: intanputri@upnvj.ac.id
}

\begin{abstract}
The emergence of the internet and social media has changed the ease of interaction and the position of humans where they are no longer just as consumers, but as well as producers and distributors of messages. Whatsapp as the top three social media platforms that are widely used in Indonesia is one of the most common social media circulating information on hoaxes and hate speeches. With the massive information circulating on social media, digital literacy in new media has a very significant role. Lecturers as professional and well-educated people should be able to understand, analyze, assess, and criticize every information carried by social media. But lately there have been various cases of misuse of social media involving lecturers to the realm of law. This will be a threat because lecturers are professions that are used as role models and key opinion leaders in the society. Therefore, researchers are interested in understanding the experience of digital literacy of lecturers as Whatsapp group users in disseminating of information on hoaxes and hate speech. Jenkins's theory of new media literacy is used in this qualitative research with an interpretive constructivism paradigm. The research method uses Edmund Husserl's classical phenomenology which emphasizes the essence of the subject (human consciousness) and its activities. The results show that Whatsapp Group is used as a form of communication and information exchange. Sharing is caring has a strong influence on lecturers to spread all the information that is on Whatsapp Group. The main reason for disseminating information related to perceptions of interests and usefulness of the information, so that sometimes the lecturers unwittingly spread hoaxes and hate speech.
\end{abstract}

Keywords: Social Media, New Media Literacy, Hoax Information, Hate Speech, Whatsapp Group

Abstrak. Munculnya internet dan media sosial telah mengubah kemudahan interaksi dan posisi manusia di mana mereka tidak lagi hanya sebagai konsumen, tetapi juga sebagai produsen dan distributor pesan. Whatsapp sebagai tiga platform media sosial teratas yang banyak digunakan di Indonesia adalah salah satu media sosial paling umum yang menyebarkan informasi tentang tipuan dan kebencian. Dengan banyaknya informasi yang beredar di media sosial, literasi digital di media baru memiliki peran yang sangat signifikan. Dosen sebagai orang profesional dan berpendidikan harus dapat memahami, menganalisis, menilai, dan mengkritik setiap informasi yang dibawa oleh media sosial. Namun akhir-akhir ini telah terjadi berbagai kasus penyalahgunaan media sosial yang melibatkan dosen hingga ranah hukum. Ini akan menjadi ancaman karena dosen adalah profesi yang digunakan sebagai panutan dan pemimpin opini kunci di 
masyarakat. Oleh karena itu, para peneliti tertarik untuk memahami pengalaman literasi digital dosen sebagai pengguna grup Whatsapp dalam menyebarkan informasi tentang hoaks dan ujaran kebencian. Teori Jenkins tentang literasi media baru digunakan dalam penelitian kualitatif ini dengan paradigma konstruktivisme interpretif. Metode penelitian menggunakan fenomenologi klasik Edmund Husserl yang menekankan esensi subjek (kesadaran manusia) dan aktivitasnya. Hasil penelitian menunjukkan bahwa Whatsapp Group digunakan sebagai bentuk komunikasi dan pertukaran informasi. Berbagi kepedulian memiliki pengaruh yang kuat pada dosen untuk menyebarkan semua informasi yang ada di Whatsapp Group. Alasan utama untuk menyebarkan informasi terkait dengan persepsi minat dan kegunaan informasi tersebut, sehingga terkadang para dosen tanpa disadari menyebarkan kebohongan dan kebencian.

Kata kunci: Media Sosial, Literasi Media Baru, Informasi Hoax, Hate Speech, Whatsapp Group

\section{Introduction}

The number of internet users in Indonesia in 2017 has reached 143.26 million people, equivalent to 54.68 percent of the total population of Indonesia. The number shows a significant increase of 10.56 million from the survey results in 2016 (Press Release No. 53 / HM / KOMINFO / 02/2018). This makes Indonesia ranked eighth in the world out of a total of 3.4 billion users or 50 percent world population. According to data of WeAreSocial, the average Indonesian uses the internet per day via a Personal Computer (PC) or smartphone for 4 hours 42 minutes. Whatsapp is the top three social media that is often used by Indonesian people. Various characteristics of Whatsapp such as user-friendly usage for various ages, the existence of Whatsapp Group, Whatsapp Call, Status to share stories, video and picture sharing, and so on, making that instant messaging applications that are identical to green colour are very popular among Indonesian people.

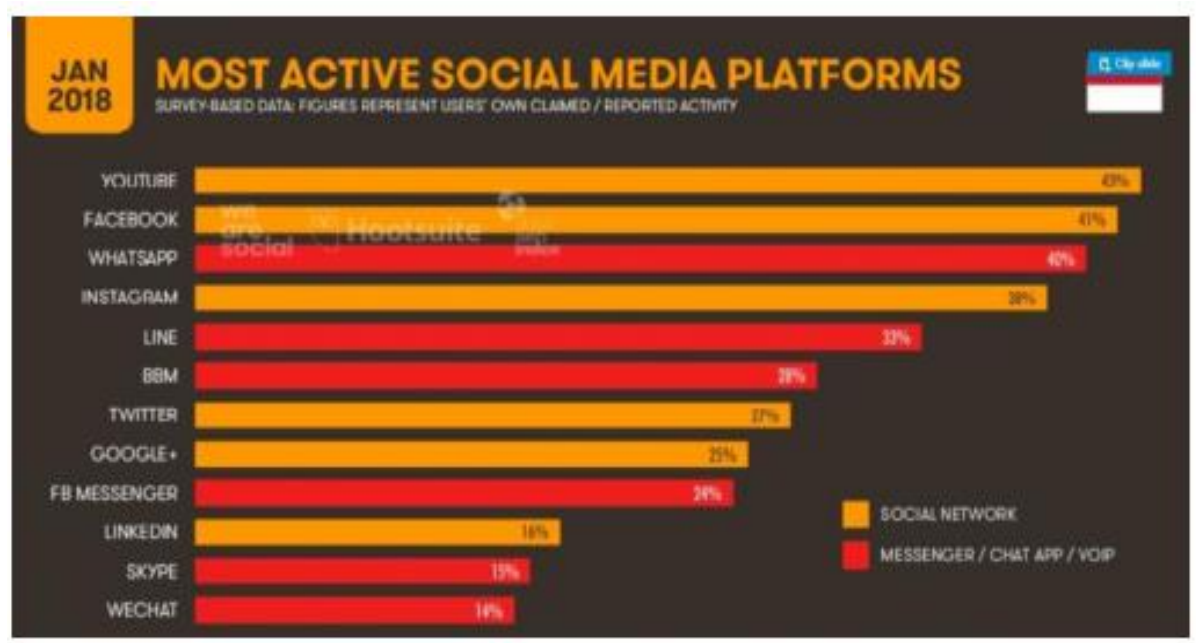

Figure1. Most Active Social Media Platforms in Indonesia (Source: wearesocial.com) 
Since the ease of interaction is provided by information and communication technology, especially the internet, the position of human to the message brought by the media has changed, not only as consumers, but also as producers and distributors. Various kinds of information are exchanged, including information on hoaxes and hate speeches. The last few years, especially in early 2017, these two phenomena have become very massive. The term Hate Speech itself became popular after the Indonesian National Police issued a Circular Letter (SE) on hate speech on October 8, 2015 with SE / 06/2015 numbers. Almost every day we can find posts on social media containing information on hoaxes and hate speeches (especially political issues, ethnicity, religion, race, and inter-group relations), which also extends to instant messaging applications such as Whatsapp Group. Each of the pros and cons of an issue claims to be the most correct and has an impact on the pattern of relationships and interpersonal communication that is not good.

Position as a producer and distributor as well as ideally can be used to control the pace of information. With massive information exposuring someone, humans should be as independent individuals able to control the message or information that information. The main controller of the message is the audience (Abrar, 2003). Abrar further emphasized that the use of communication technology always generate social changes in society; the use of computers for communication has led people to believe in the information on computers rather than the reality. While searching for information on the internet, they create reasons to find new information again and again. They give up some, if not all, of their authority on the internet. An individual user of communication technology must know exactly whether later his behavior is good and the response is proportional. By literacy of information brought by communication technology, humans will have their own authority, and will not be swayed by information uncertainty that is currently circulating. A user who is media literate will try to react and assess a media message with full awareness and responsibility (Zamroni \& Sukiratnasari, 2011, p. 84). This is where the role of media literacy, especially new media literacy becomes very significant.

According to Article 4 of UURI No.11 of 2008 concerning Information and Electronic Transactions (ITE), the use of information technology and electronic transactions is carried out with the aim of educating the nation's life as part of the world information society, developing national trade and economy in order to improve people's welfare; increasing the effectiveness and efficiency of public services, opening the widest opportunity for everyone to advance their thinkings and abilities in the field of using and utilizing Information Technology as optimal as possible and responsibly; and provide security, justice and legal certainty for users and providers of Information Technology. These five noble goals can only be achieved if someone is literate about information. As conveyed by Zamroni \& Sukiratnasari, (2011: 84), that as consumers, the society must be smart and able to choose what information is 
needed. The digital age has encouraged a flood of information in the community, including through Whatsapp Group. When the community is less responsive, as a result the information provided by the media becomes consumptive, misleading, and pragmatic, rather than providing welfare and providing security.

As educated people, lecturers should be able to understand, analyze, assess, and critique every information carried by communication technology. Unfortunately, there are even lecturers who are hegemony and help spread information about hoaxes and hate speeches when using social media. As reported by Tempo.co, the profession of civil servant lecturers dominates the report on the state civil apparatus or the ASN which spreads hoaxes and utterances of hatred. The report was revealed by the State Personnel Agency which was compiled from the Report-BKN data until May 2018. At least 14 complaints involving the ASN with the dominance of the reported workforce as lecturers. (https://nasional.tempo.co/read/1096778/bkn-dosen-pns-dominasilaporan-hoax-dan-ujaran-kebencian, accessed October 31, 2018)

Furthermore, the public was also surprised by the arrest of Himma Dewiyana Lubis, lecturer in Library Science, University of North Sumatra (USU) by the Directorate General of North Sumatra Police for linking the Surabaya bomb and hashtag of \#2019GantiPresiden in her Facebook post (https:/ / news.detik.com/berita/4029303/kaitkan-bom-surabaya- and -2019 president-lecturer-students-arrested, accessed May 20, 2018) In addition, there is also the case of Diponegoro University Professor of Law, Suteki, who was dismissed as Head of Law Master Program in Diponegoro University regarding several statuses and his comments on social media that are considered to defend the Hitzbut Tahrir Indonesia (HTI) organization and must also undergo a disciplinary session of the State Civil Apparatus (ASN) and a courtesy code of ethics. (https://www.cnnindonesia.com/nasional/20180606222408-20304123/diduga-pro-hti-guru-besar-undip-prof-suteki-disabled accessed on June 20th 2018)

The things above can be a potential threat considering that the lecturer is a profession that is used as a role model as well as a key opinion leader not only by students, but also by the society. Zamroni and Sukiratnasari (2011: 89) say that the level of literacy is usually related to the level of education and critical power of the society. The higher the education and critical power of a person, the higher the level of literacy. Therefore, researchers are interested in understanding new media literacy experiences in disseminating information on hoaxes and hate speeches among leturer as Whatsapp Group user. This research was conducted with the aim of (1) Understanding and describing new media literacy experiences among lecturers in disseminating information on hoaxes and hate speeches when using Whatsapp Group, (2) Analyzing key competencies that lecturers must have regarding new media literacy in the use 
of social media, and (3) Analyzing the processes that occur in the dissemination of information on hoaxes and hate speeches through Whatsapp Group.

\section{Literature Review}

According to Zamroni \& Sukiratnasari (2011: 89) the level of literacy is usually related to the level of education and critical power of the society. The higher the education and critical power of a person, the higher the level of literacy. But in the study of "Community Based Media Literacy" (Wiratmo, 2011), it was found that several communities that were the object of research including one of the student communities, had not been literate to the media. Likewise the research conducted by Mazdalifah (2011) with the title "Developing Media Literacy in Higher Education" shows the results of the interest of USU's FISIP Communication Science students about the study and application of media literacy curriculum in learning, but still far to arrive at measuring media literacy levels college student.

Wiratmo's research (2011) portrayed the experience of the media literacy movement conducted by LESPI Semarang on several communities. Relying on the strategic position of the community as the spearhead of disseminating media literacy issues, Wiratmo used the definition of media literacy by Sonia Livingstone (2004), namely the ability to access, analyze, evaluate and make messages in various contexts. This model according to Livingstone can be applied to conventional media and new media. In the case brought by Wiratmo, where the object of his movement was a variety of communities, there were several problems that Livingstone could not yet embrace such as the materialdemographic gap, social and symbolic resources, gaps in accessing knowledge, online communication and participation that would continue. The results of the movement's evaluation state that what LESPI has done has not achieved results as limits to the ability to access, analyze, evaluate and create content according to Livingstone. But on the other hand, Livingstone has offered a media literacy theory that fits the character of new media and displays it quite simply and densely (quite complete).

Mazdalifah (2011) also documented the media literacy movement towards students of the Faculty of Social and Political Sciences in the University of North Sumatra who included media literacy material into the education curriculum, especially the "Media and Society" courses since 2009. The strategy of incorporating media literacy in teaching this course was considered effective in introducing and developing media literacy to students. Based on observations, there are not many students who understand what media literacy really is. This movement instilled a variety of theories and media literacy issues in Indonesia for students during lectures.

Previously, Students become the object of research that discusses students' literacy skills in the undergraduate level. Two studies departing from 
the evaluation of media literacy movements imposed on students, resulting in students not yet literate towards the media. These different results show the complexity of media literacy skills. Therefore it is important to explore media literacy in the academic community with a higher level of education, specifically lecturers where the minimum qualifications are at the level of master or doctoral degree.

Therefore this study aims to see new media literacy among lecturers. In addition, new media literacy in this study is more specific to Whatsapp Group, in contrast to the three previous studies that measured literacy in all types of media. Tracing new media literacy experiences among lecturers in disseminating information on hoaxes and hate speeches, media literacy research that departs from the awareness of lecturers' communication behavior, has also never been found by researchers in Indonesia.

\section{Hoax Information}

Hoax in the Oxford Dictionary (2017) is interpreted as a form of fraud whose purpose is to make humor or bring danger. Hoax in Indonesian means hoax, false information, or fake news. Whereas according to the English dictionary, hoax means banter, false stories, and deceiving aliases. Walsh (2006) stated the term hoax already exists since 1800 the beginning of the industrial revolution era in England. Hoax is a word that is used to indicate false coverage or an attempt to deceive or outsmart the reader to believe something. News that is not based on reality or truth (nonfactual) for certain purposes. The purpose of hoaxes is just a joke, fad, to shape public opinion. The point is that hoaxes are misguided and misleading, especially if internet users are not critical and directly share the news that is read to other internet users (Juditha, 2018). Therefore, in this study the term "hoax information" was chosen as one of the research concepts. The choice of this term is based on the basic understanding of the word hoax itself (deception), and its form in the form of information when distributed (as an object) on Whatsapp Group. Thus "hoax information", what is meant in this research is "hoax information".

According to David Harley (2008), there are some practical rules that can be used to identify hoaxes in general. First, hoax information usually has the characteristics of chain letters. Second, hoax information does not usually include the date of the event or does not have a realistic or verifiable date, such as "yesterday" or "issued by ..." statements that do not indicate clarity. Then the third, hoax information usually does not have an expiration date on information warnings, even though the actual presence of that date will not prove anything, but can cause prolonged anxiety. Fourth, no identifiable organization is cited as a source of information or includes an organization but is usually not related to information.

Harley himself made a guide to recognize hoax information and chain emails because of the many reports about hoax information and chain e-mails 
circulating, causing unrest in the society. Although confirmed, obsolete and irrelevant, this information continues to circulate, so that a guide to recognizing and dealing with hoaxes is very important. The characteristics of hoax information and chain e-mails presented by Harley are in accordance with the three hoax information disseminated by students in their respective Whatsapp groups, which include sentences that invite the widest dissemination of information, do not include dates and deadlines, do not include valid sources and use the names of two large companies. Although in information that contains the date of creation / dissemination and expiration date of information also sometimes could not prove that the information is not a hoax, these four characteristics can at least help us in focusing our locus of thought when dealing with information. So ideally we should be skeptical of any information encountered even if it looks right, complete, and very convincing.

According to David Harley (2008), several types of hoaxes, including gift hoaxes (mentioning that you won a number of prizes), hoaxes of sympathy (spreading information about people who are sick, needing help or kidnapping) and urban legend (spreading about certain branded perfumes doesn't last long). Harley said that hoax information will continue to grow along with the development of the times. There is also information that is in essence true but questionable uses and values, called Harley with semi-hoaxes.

Harley (2018) stated further that most hoax information circulates from good intentions to show attention or help others. But there is also information about hoaxes that are intended for personal pleasure when successfully deceiving others. What's important about hoax information is its spread to the public, spreading in large numbers. To deal with it, we must think critically (even skeptically) by issuing such arguments: "Bill Gates will not enter the ranks of the richest people by giving his money as gifts to people who want to spread emails about him". If we disseminate information without checking the truth, Harley (2018) judges it as an act that is both naive and lazy. It shows that the person does not have critical thinking and scepticism. This is in line with the concept of media literacy which requires someone to commit to using a critical perspective and take the time to verify the information we meet.

\section{Hate Speech}

Hate Speech or often called hate speech is an act of communication carried out by an individual or group in the form of provocation, incitement, or insult to other individuals or groups in terms of various aspects such as race, color, ethnicity, gender, disability, sexual orientation, citizenship, religion, etc. (Judhita, 2017). In the legal perspective, Hate speech is a word, behavior, writing, or performance that is prohibited because it can trigger acts of violence and prejudice whether from the perpetrator of the statement or the victim of the action. Websites that use or implement Hate Speech are called Hate Site. Most 
of these sites use the Internet and News Forums to emphasize a certain point of view (Harefa, 2017).

The term Hate speech is a modern example of the Newspeak novel, when Hate speech is used to provide covert criticism to poorly implemented and hasty social policies as if they appear to be politically correct. Until now, there is no legal definition or definition of what is called Hate speech and defamation in the Indonesian language. In English, defamation is defined as defamation, libel, and slander which if translated into Indonesian is slander (defamation), oral slander (slander), written slander (libel). In Indonesian, there is no legal term to distinguish the three words (Harefa, 2017).

\section{Theory of New Media Literacy}

Jenkins' new media literacy theory (2009) was chosen in this research because the phenomenon studied was the use of one of the social media, namely Whatsapp. This theory is considered the most able to explain in detail the character of new and practical media to see the literacy of media possessed by lecturers in the dissemination of information on hoaxes and hate speeches.

Jenkins et al (2009) formulated new media literacy with twelve core new media literacy abilities. This theory is very practical based on new media characters. As explained earlier, the new media literacy theory by Jenkins et al is very practical based on new media characters. Because of complexity of new media, Jenkins et al (2009) divides the core divide into twelve media literacy skills namely play, performance, simulation, appropriation, multitasking, distributed cognition, collective intelligence, judgment, transmedia navigation, networking, negotiation, visualization. The breakthrough made by Jenkins et al with the twelve core capabilities required is highly technical in new media. For example the first ability is play, which means not only the ability to access, but also explore the ICT that is faced. This is in accordance with the smartphone platform that can accommodate many applications that require each ability to use it, to meet the user's needs for the application. In addition, the technical nature also causes this theory to be practical enough to measure a person's media literacy against new media.

Following is an explanation of each of the 12 core new media literacy abilities of Jenkins et al.

\section{a. Play}

Play ability is defined as the ability to use. Using in the sense not only accessing, but also exploring new media which is used. According to Jenkins, new media users must explore and find out the ins and outs of new media applications that are used. This will shape the user's relationship with the mind, community and environment in the gadget (interaction in it) and increase the user's knowledge. That way, the more we use the media, the more we literate it (Jenkins, 2009). 


\section{b. Simulation}

Simulation ability is defined as the ability to interpret and pervert media message information. This ability was announced by Jenkins so that humans can make peace with the sea of information. This ability is obtained through experimenting, hypothesizing, testing with update variables. Direct experiments such as this make people understand better, enrich experiences and possibilities for new discoveries, test theories through trial and error, as experts find and infer the nature of the virtual world. Awareness of this simulated experience is a continuation of awareness of media activities that have been passed through the ability to play or use the media (Jenkins, 2009).

\section{c. Performance}

Performance is the ability to play roles or adopt alternative identities in the purpose of improvisation and exploration of learning something. Something that is meant here is knowledge and experience around using new media. According to Jenkins, by carrying out these roles can foster a wealth of understanding of the human self itself and its social role, including the way they are connected with people in the virtual environment, so that it helps and can be applied in real life. The ability to adopt a variety of identities makes people able to understand the perspectives of others, other roles, other countries, at other times (context), social interactions, social positions, both in the real and virtual worlds. Therefore, the more humans master this ability, the more literate human media is (Jenkins, 2009).

\section{d. Appropriation}

The ability of appropriation is defined as a process in which humans take part in a culture and unite it with various media content. The form can be music, subtitles, fashion, or a picture. The more human mastery of this ability will increasingly media literacy because from this process humans learn and think more deeply about the culture to be used, ethics and the legal implications of creating media content (Jenkins, 2009).

\section{e. Multitasking}

Multitasking is the ability to scan the environment and shift focus to the details of message elements. There are two things that must be considered in this ability. First, attention or attention, namely the ability to criticize, filter out foreign information and focus on the most detailed details of the information environment, thereby preventing the abundance of information by controlling information that enters human short-term memory. Second, scan and map information into their respective categories, so as to reduce the entry of information into short-term memory. Multitasking capabilities improve the method of monitoring and responding to the ocean of information circulating around us. The world context that shifts quickly by the presence of new media 
lies behind this ability. Humans must be able to distinguish between working on a task by doing several jobs at once (multitasking) (Jenkins, 2009).

\section{f. Distributed cognition}

Distributed cognition is the ability to interact meaningfully with equipment (new media) that broadens human mental capacity. What is meant by meaningful interaction here is to realize the role of each element in new media. While what is meant by mental capacity is the capacity to solve problems that occur in interactions in new media and then apply them in real life everyday. So the perspective of this ability is to bring distributed intelligence between the brain, body and the real world (Jenkins, 2009).

\section{g. Collective intelligence}

Distributed cognition is the ability to unite knowledge and compare opinions with others towards a common goal. In new media, communities often form that occur due to an interest in something. In this community there is sharing of knowledge about the things that are popular. Community knowledge such as this changes the nature of media consumption, shifting from a form of personal media centered on the digital revolution, towards social / communal media centered on the culture of media convergence (Jenkins, 2009).

\section{h. Judgment}

Judgment is the ability to evaluate the reliability and credibility of different information sources. Even though information is shared from people who have the same interests (in the community for example), information is not necessarily credible. Jenkins compares Wikipedia and the Encyclopedia Britannica to explain this. The results show the same level of credibility. That is, reliable sources also have the possibility of disability. Therefore humans must think of reading all sources of information from a critical perspective. Humans must be able to distinguish between facts from fiction, arguments from documentation, truth from forgery (Jenkins, 2009).

\section{i. Transmedia navigation}

Transmedia navigation is the ability to follow the flow of stories and information between multiple suppositions. In the era of convergence, consumers become hunters and information gatherers, to draw information from several sources and make new syntheses. Therefore humans must be adept at reading and writing through images, text, sounds and simulations. The most basic transmedia stories are those told in several media. This ability enhances learning to understand relationships between different media systems (Jenkins, 2009).

\section{j. Networking}


Networking is the ability to search, synthesize and disseminate information. In a world where knowledge is produced collectively and communication occurs between media, the capacity to network emerges as a social and cultural ability. This ability increases the ability to surf between different social communities. Participation in large-scale social communities is an investment in collecting and recording data for other users. The active participation is needed and depends on the social ethos for sharing knowledge. Others depend on automatic analysis of collective behavior (from social and psychological factors) (Jenkins, 2009).

\section{k. Negotiation}

Negotiation is the ability to navigate various communities, understand and appreciate a variety of perspectives and adhere to and follow various norms in each community. The flow of communication in new media can make culture run easily. Humans can form communities without even knowing each other, cultural diversity in them can be a problem. So that people will build an understanding of the context of cultural diversity that occurs in the community. This context is read through prejudices and assumptions that already exist in each member (not everyone can accept diversity). This also risks creating conflicts of values and norms. Negotiations in this case exist in two ways, namely on different perspectives and on the diversity of communities (Jenkins, 2009).

\section{Visualization}

Visualization is the ability to create and understand visual representations of information in the purpose of expressing ideas, finding patterns and identifying trends.

The Thinking Framework in this study is clearly described as follows

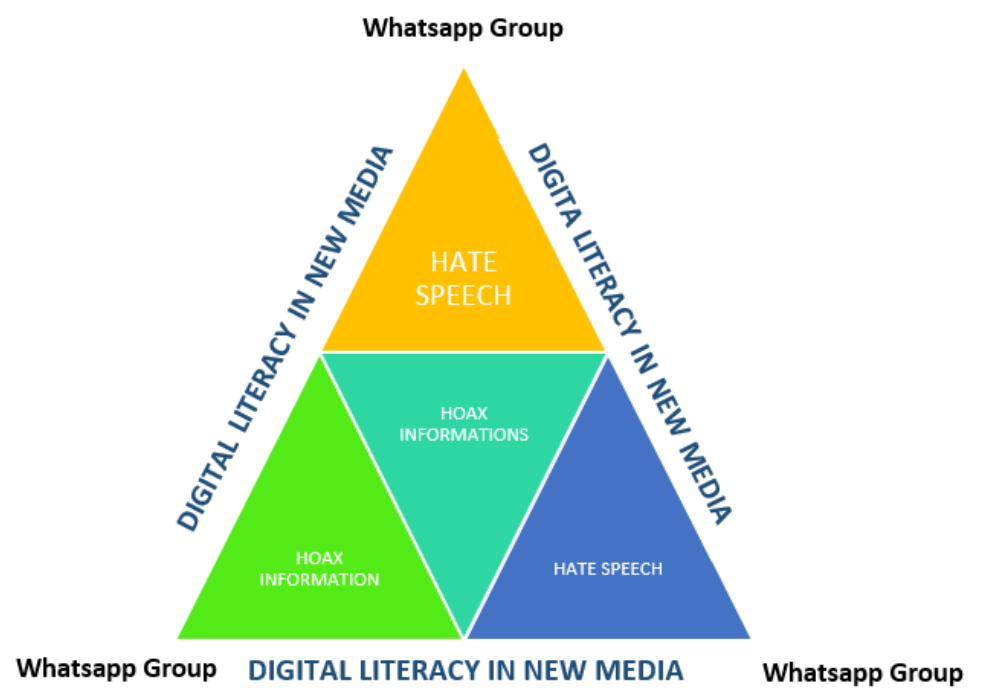

Figure 2. Conceptualization of Concept Theory 


\section{Research Methods}

This type of research is qualitative with constructivist paradigm that is interpretive. In this study, researchers placed empathy and dialectical interaction between researchers and research subjects to answer research questions. The type of research used in this study is Edmund Husserl's classic phenomenology which emphasizes the essence of the subject (human consciousness) and its activities (as cited in Abidin, 2011: 160).

The media literacy studied here aims at the authority of the human self on social media content in any form. So that this study emphasizes human consciousness and the activities it does when meeting information in the media. Not only seeing or observing media behavior and attracting its meaning, but exploring the awareness of research informants in media activities starting from when they meet information to disseminating that information. As a research method, phenomenology is a way of building an understanding of reality, seen from the point of view of social actors who experience events in their lives. (Fortune, 2011: 139)

This study looks at the experience of social actors, namely lecturers at universities in Central Java, related to new media literacy in disseminating information on hoaxes and hate speeches when using Whatsapp Group. Data collection of this research was conducted through two methods, namely observation and in-depth interviews. First, an observation method in which researchers only act to observe without participating in activities such as those conducted by researched groups whether their presence is known or not. (Kriyantono, 2008: 110)

This observation is needed by researchers to observe the spread and confirmation if the information is hoaxes and hate speeches as well as information dissemination behavior of research informants. Second, the method of in-depth interviews, where researchers conduct continuous interviews to gather information from respondents, especially to understand the new media literacy of lecturers in various universities in Central Java in disseminating information on hoaxes and hate speeches when using Whatsapp Group.

The method of analysis and interpretation of the data used in this study is the analysis and interpretation of phenomenological data. The following stages of analysis and interpretation of phenomenological data are carried out after adjusting to research needs (Fortune, 2011: 143-144):

1) Categorization of a number of data in conceptual themes that have been determined by researchers, namely new media literacy skills, knowledge of hoax information, and motivation to spread information by informants, based on the communication experience that has been described. 
2) Describe each conceptual category of each informant by including an answer quote from the informant, so that the explanatory results are really a portrait of the reality that happened.

3) Describe the meaning of consensus or social construction from the conceptual description of each informant (compare and contrast) before concluding it.

4) Synchronization between research findings (new media literacy skills Informants related to receiving and disseminating information on hoaxes and hate speeches, knowledge of information on hoaxes and hate speeches, and motivation to spread information on hoaxes and hate speeches) with the initial concepts (theories) of research.

5) Explanation of research findings on reality armed with theories with various perspectives (Abrar, 2005). The use of a variety of perspectives is carried out to open opportunities for the study of Communication with sciences in other fields.

6) Formulate interesting findings in the study.

\section{Results \& Discussions}

Social media makes it easy for users or members to easily participate, share and create good in the form of blogs, social networks, wikipedia, forums or even in the form of communities that are built online in virtual space. The easier facilities to access the internet make the development of social media is very rapid and many people even use it this one media for personal, business and information dissemination hoax and hate speech. Referring to the opinions raised by Buente and Robbin (2008), where they conducted studies or investigations about the trends of American information internet activities between March 2000 and November 2004. The results of the research were four dimensions of internet use, namely information utility, leisure or fun activities, communication, and transactions.

\section{Sharing is caring as strong influence in spreading hoaxes and hate speech}

Based on the research that has been done, Whatsapp Group is used as a form of communication and information exchange as well as for fun places. Their Whatssap groups vary. There are groups affiliated with professions or occupations such as university groups, faculty groups, department groups, and groups of lecturer associations. But there are also groups that are more personal in nature, such as groups of school friends and campus friends, as well as family groups. The types of information exchanged also vary such as the information obtained varies greatly from education, teaching professions, economics, politics, religion and information about households.

Some of the informant's activities on Whatsapp Group showed that there were activities in giving comments, responding according to their competence as lecturers and individuals. There is even an activity to disseminate 
information both hoaxes and hate speeches. The reasons stated include aiming to inform others about the truth of information and for a reason due to concern about something, community participation or interest in certain things.

When receiving messages on Whatsapp Group, information is usually forwarded directly to other parties, either individually, to the public or in their groups. Informants have their own satisfaction when they have disseminated information to others, it is like having helped someone in need. And they still believe that sharing is caring is true, including when using Whatsapp Group.

Reluctance often occurs when you want to cross check the correctness of the information they receive and finally the information will delete and silence the information they receive and add / replace the information obtained into new information. Hoaxes and hate speeches that are spread by various types, ranging from information that is currently happening at the moment or viral in social media, as well as related to the interests and relevance of informants about something. Can be political, religious and information on daily life. The most common of hoaxes that are distributed include (1) Fake news, which is news that attempts to replace the original news. This news aims to falsify or incorporate untruth in a news story. False writers usually add things that are not true and conflict theory, the stranger, the better. False news is not a humorous comment on a story. (2) Clickbait, which is a link that is placed strategically on a site with the aim of attracting people to other sites. The content in this link is in accordance with the facts, but the title is made excessive or interesting images are installed to provoke the reader, (3) Confirmation bias, namely the tendency to interpret new events as well as evidence of existing beliefs, (4) Misinformation: Information wrong or inaccurate, especially those intended to cheat, and (5) Post-truth: Post-truth: An event in which emotions play more roles than facts to shape public opinion.

\section{Perception of Interest and Usefulness}

Information on hoaxes and hate speeches is usually obtained regarding what is happening (situations and conditions) at that time. The main factors that spread or not information on hoaxes and hate speeches are dependent on interests, interests and usefulness of the information for others. According to the psychological view, there are other factors that cause users to easily believe in hoax information. Basically, user behavior is more likely to believe hoax information, if the information is in accordance with the opinions or attitudes they have (Respati, 2017). The results of the study also support the opinion of David Harley in the book Common Hoaxes and Chain Letters (2008), which identifies hoaxes in general. First, hoax information usually has characteristics of chain letters by including sentences like "Share this to everyone you know, if not, something unpleasant will happen ". Second, hoax information does not usually include the date of the event or does not have a realistic or verifiable date, such as "yesterday" or "issued by ..." statements that do not indicate clarity. Then the third, hoax information usually does not have an expiration 
date on the information warning, even though the actual presence of that date will not prove anything, but it can cause an anxiety effect prolonged. Fourth, there is no identifiable organization quoted as a source of information or includes an organization but is usually not related to information.

Positive feelings will arise in a person if his opinion or belief gets acknowledged and tends not to care whether the information he receives is true or false. They will redistribute the information without a filter. This condition is exacerbated if the information disseminator hoaxes and hate speech has less knowledge in utilizing the internet. The tendency to overuse the internet to search for information so that it is possible to experience information overload, so often information Hoax and hate speech easily receive and disseminate to other parties without first seeing the benefits and harm for others. Other trends, user behavior see the headline (head line) without looking at the contents of the news and they immediately thought that the information was correct. Moreover, it is supported by people sending information from friends who are trusted or from credible media, so they immediately make comments based on news titles. On the other hand there are symptoms of people on social media contributing to a theme so that they can be understood. A news that is trending topic or viral in the media has a tendency to be spread more, without any prior verification efforts, so as not to appear to be left behind. By spreading a story that is widely talked about, people can know and are considered legitimate as knowledgeable people. Hoax spread behavior through social media is strongly influenced by news makers both individually and in groups, from low to high education, and neatly structured. (Lazonder, Biemans, \& Wopereis, 2000)

Basically, every person has responsibility for the information they receive. The behavior of social media users has emotional feelings when they get bad news or news of someone's tragedy and feel they have a moral responsibility to share. That time no longer cared whether it was a hoax or not? On social media, people feel they have a burden to share their suffering can be a lesson for other users or want to release the burden to feel better. Users want comments or likes and are often shared without prior verification. The habit of social media users' behavior not to be blamed if information is hoax, they add the words "from the other group" as a preventive measure so that if the news is a lie. This behavior is an effort to escape from the responsibility of truth. Information from broadcasts is very difficult to verify and track who the initial spreader is.

\section{Conclusions \& Recommendations}

\section{Conclusions}

The results show that Whatsapp Group is used as a form of communication and information exchange. Sharing is caring has a strong influence on lecturers to spread all the information that is on Whatsapp Group. The main reason for disseminating information related to perceptions of 
interests and usefulness of the information, so that sometimes the lecturers unwittingly spread hoaxes and hate speech.

\section{Recommendations}

Based on the results of this research, some suggestions from researchers are as follows:

1. Social media should be used wisely

2. Information on hoaxes or hate speeches should first be traced to the truth of the info and sources

3. Avoid provocative information or hate speeches

4. Avoid minimal emotional involvement in commenting on the social world

5. Filter information before spreading it

\section{References}

Abidin, Z. (2011). Filsafat Manusia. Bandung: PT. Remaja Rosdakarya.

Abrar, A. N. (2005). Terampil Menulis Proposal Penelitian Komunikasi. Yogyakarta: Gadjah Mada University Press.

Adiputra, W. M. (2008). Literasi Media dan Interpretasi atas Bencana. Retrieved Juni 12, 2014, from Jurnal Ilmu Sosial dan Ilmu Politik: www.ugm.ac.id

Antara. (2018, June). BKN : Dosen PNS Dominasi Laporan Hoax dan Ujaran Kebencian. Retrieved October 31, 2018 , from https:/ / nasional.tempo.co/read/1096778/bkn-dosen-pns-dominasilaporan-hoax-dan-ujaran-kebencian

Buente W ,dan Robbin A. 2008. “Trends in Internet Information Behavior: 20002004".

Harley, D. (2008). Common Hoaxes and Chain Letters. San Diego: ESET, LLC.

Jenkins, H., et al. (2009). Confronting the Challenges of Participatory Culture. London: MIT Press.

Juditha, C. (2017). Hatespeech di Media Online: Kasus Pilkada DKI Jakarta 2017. Jurnal Penelitian Komunikasi dan Opini Publik, 21(2), 137-151.

Juditha, C. (2018). Hoax Communication Interactivity in Social Media and Anticipation (Interaksi Komunikasi Hoax Di Media Sosial Serta Antisipasinya). Pekommas, 3(1).

Kriyantono, R. (2008). Teknik Praktis Riset Komunikasi. Jakarta: Kencana.

Lazonder, A. W., Biemans, H. J. a, \& Wopereis, I. G. J. H. (2000),. Differences between novice and experienced users in search information on the 
World

Wide

Web.

https:/ / doi.org/10.1002/(sici)10974571(2000)51:6<576::aid-asi9>3.0.co;27

Mazdalifah. (2011). Mengembangkan Literasi Media di Perguruan Tinggi. In D.

Herlina, Gerakan Literasi Media Indonesia. Yogyakarta: Rumah Sinema.

Rahmawati, N., Syahrin, A., \& Mulyadi, M. IMPLIKASI PERUBAHAN UNDANG-UNDANG INFORMASI DAN TRANSAKSI ELEKTRONIK TERHADAP TINDAK PIDANA UJARAN KEBENCIAN (HATE SPEECH). Jurnal Mahupiki, 1(01).

Rejeki, N. S. (2011). Fenomenologi: Metode Penelitian untuk Memahami Pengalaman Komunikasi. In A. Ishak et al., Mix Methodology dalam Penelitian Komunikasi. Yogyakarta: Buku Litera.

Respati, S. (2017) Mengapa Banyak Orang Mudah Percaya Berita "Hoax"? Kompas.com.

Retrieved

from http:/ / nasional.kompas.com/read/2017/01/23/18181951/mengapa.ba nyak.orang.mudah.percaya.berita.hoax.

Rizqo, Kanavino Ahmad. (2018, May). Kaitkan Bom Surabaya dan \#2019GantiPresiden,Dosen USU ditangkap. Retrieved May 20, 2018) from https://news.detik.com/berita/4029303/kaitkan-bom-surabayadan-2019gantipresiden-dosen-usu-ditangkap

Sinuko, Damar. (2018, Juni). Diduga Pro-HTI, Guru Besar Undip Prof Suteki Dinonaktifkan. Retrieved June 20, 2018), from https:/ / www.cnnindonesia.com/nasional/20180606222408-20304123/diduga-pro-hti-guru-besar-undip-prof-suteki-dinonaktifkan

Walsh, L. (2006). Sins against science: the scientific media hoaxes of Poe, Twain, and others. SUNY Press.

Wiratmo, L. B. (2011). Literasi Media Berbasis Komunitas. In D. Herlina, Gerakan Literasi Media Indonesia Yogyakarta: Rumah Sinema.

Zamroni, M., \& Sukiratnasari. (2011). KPID DIY Membumikan Literasi Media Bagi Masyarakat di Daerah Istimewa Yogyakarta. In D. Herlina, Gerakan Literasi Media Indonesia. Yogyakarta: Rumah Sinema 